\title{
THE EFFECTS OF RISING SEA LEVELS ON THE CONSERVATION OF ROMAN FISH TANKS IN THE WESTERN MEDITERRANEAN BASIN
}

\author{
F. J. Caballero ${ }^{1, *}$, M. J. Viñals ${ }^{1,2}$, S. Tormo ${ }^{1}$ \\ ${ }^{1}$ Universitat Politècnica de València, Valencia, Spain - fjcaballero.arq@ gmail.com,mvinals@cgf.upv.es, santores@arq.upv.es \\ ${ }^{2}$ Research Centre PEGASO, Universitat Politècnica de València, Valencia, Spain
}

Commission II - WG II/8

KEY WORDS: Roman, Fishponds, Rising sea level, Coastal heritage, Underwater heritage, Risks, heritage

\begin{abstract}
:
The continuous sea level rising affects all those built heritage elements located near the seacoasts and oceans all over the world. Some of the most affected sites are the found Roman coastal fish tanks which were scattered along the coast of the Mediterranean Sea and had the purpose of breeding and keeping the fish in captivity. This study will analyze the current consequences of this phenomenon in these sites, mainly on those located in Spain. It will also analyze the effects in structures because of their submergence, the effects of erosion, the different reasons for coast line variations, the risks of sea storms and floods. Estimations are also made and they are based on the forecasts of sea-level rises in order of what it is being published in scientific fields. Finally, the pernicious effects that these types of infrastructures and their associated elements will suffer in a short or medium term will be studied.
\end{abstract}

\section{INTRODUCTION}

During the Holocene, the sea level rise happened by natural causes. During the recent years, the acceleration of this process has been associated with man-induced phenomena and this is the result of the climate change situation that affects the stability of coastal areas.

A lot of scientific documentation has been published on this subject, and dramatic examples of the impotence of man in the face of this evidence are now happening in the Mediterranean coast, such as the case of the last extraordinary tides that occurred in November 2019 in Venezia (Italy) or the marine storm 'Gloria' that have hit the Spanish coasts of Valencia and Catalonia during January 2020.

Climate change is a phenomenon that also has its consequences on heritage, especially on the elements in risk that are near the sea. In these cases, their safeguarding is not guaranteed, even when having the will to protect them

The typology of heritage elements that we usually find on the coast are port type: fishing or commercial infrastructure (docks, harbours, etc.) and processing factories of marine products (fish tanks or ponds, fish salting factories, etc.). Both of them are next to the coastline or slightly submerged. Some of these elements date back to even Roman times, so, in addition to their heritage value, they hold a relevant historical-social value.

Furthermore, these constructions are particularly important in order to define the Roman sea level. This is reflected in the work of Lambeck et al. (2004), since they were built considering the level of seawater for their proper functioning.

The present work is focused on the analysis of the situation in which the Roman fish thanks (piscinae) were used to storage alive fish and built or excavated into the shoreline rock of the western Mediterranean coast (central Tyrrhenian coast of Italy and central Mediterranean coast of Spain). These are regions where the development of piscinae reached its greatest concentration in Roman time and where many well-preserved remains are still found nowadays.

\section{METHODOLOGY}

In order to research into this topic, specific bibliography was reviewed in different libraries in Rome, including several from the University of Sapienza, the German Archeological Institute and the Spanish School of History and Archeology in Rome, as well as existing publications edited by different public organizations of Spain.

During the search for information, the keywords used were: 'fishpond', 'fish tank', 'fish farming', 'sea level in ancient times', 'piscinae', 'vivarium'... Although documents in Spanish, Italian, English and French were sought, it seems that results of this bibliographic search are not very extensive in this subject. A total of 12 books contained the matter in some way but, specifically and in depth, only 3 of them were addressed to the fish tanks; only 1 talked about the influence of the sea level on these elements. Meanwhile in scientific papers, numerous descriptive texts from different places have been detected; however, just a few of them addressed the issue of the risks faced by this type of heritage.

Observational field work was carried out in the five Roman fish tanks in Spain; Port La Nautique, close to Narbonne (France); as well as other settlements in Italy, such as: Santa Liberata, Cosa, Pian di Spille, Torre Valdaliga, La Mattonara, Punta dellaVipera, FossoGuardiole, Villa delleGrotacce, Santa Severa, Torre Flavia, La Saracca, La Banca, Torre Astura, Sperlonga, Formia, Isola Ventotene, Miseno and Bagni Salvatore).

A photographic record of the current state in which these elements are found was taken and compared with the data and images extracted from the scientific documentation and bibliography. Then, a comparison was made to detect the variations suffered during the last years.

\footnotetext{
* Corresponding author
} 


\section{MEDITERRANEAN PISCINAE}

The Roman fish tanks, or piscinae, are located along Mediterranean coasts. The higher density is set upon the coast of the Tyrrhenian Italy, with approximately 50 identified sites. Throughout the Spanish peninsular coasts, 4 installations were identified in the Mediterranean, all of them in the province of Alicante (Olcina, 2015). There is also another possible installation in the area of Cape Trafalgar in the Atlantic Ocean (Bernal, 2011). Figure 1 shows these locations.

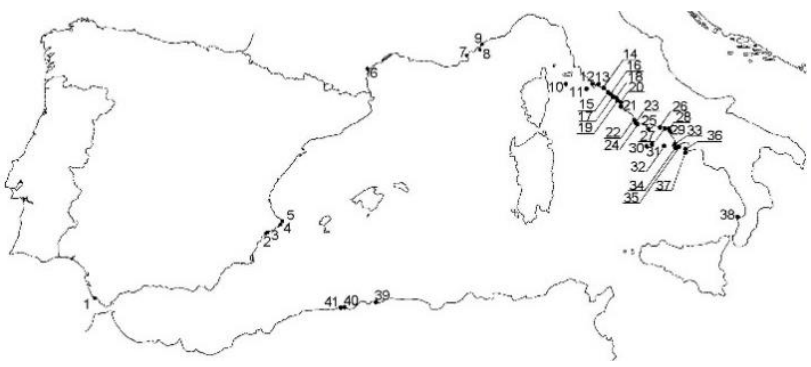

Figure 1. Map location of the most well known Roman piscinae in the Western Mediterranean Sea: 1.Cape Trafalgar; 2.La

Albufereta; 3.Illeta dels Banyets; 4.Baños de la Reina - Calp;

5.Baños de la Reina - Xàbia; 6.Port-La-Nautique; 7.La

Gaillarde; 8.Ilê Sainte Marguerite; 9.Antibes; 10.Isola Pianosa;

11.Isola Giglio - Saraceno; 12.Santa Liberata; 13.Cosa; 14.Pian

di Spille; 15.Torre Valdaliga; 16.La Mattonara; 17.Punta della

Vipera; 18. Fosso Guardiole; 19.Villa Grotacce; 20. Santa

Severa; 21.Torre Flavia; 22.La Saracca; 23.La Banca; 24.Torre

Astura; 25.Lago di Paola; 26.Sperlonga; 27.Fontania;

28.Formia; 29.Scauri; 30.Ponza; 31.Zanone; 32.Ventotene;

33.Torregaveta; 34.Miseno; 35.Cento Camerelle; 36.Bagni

Salvatore; 37.Bagnidella Regina Giovanna; 38.Torre Sant'Irene;

39.Le Figuer; 40.Tipasa; 41.Cherchell.

These Roman piscinae have open-air constructional elements which are carved into the rock (calcareous sandrocks or limestones) to a depth of $2.7 \mathrm{~m}$ or less (depending on the fish species), according to the data from Lambeck et al. (2004). They have different basins or containers which have the purpose of separating the fish population by size, and they are protected from waves and the storm action by exterior walls (Figure 2). There are also a number of samples of installations excavated in gallery form. They are mostly located in the surroundings of Naples and the Pontine Islands (Giacopini, et al., 1994).

These fish tanks were always practically linked to the existence of a villae or other industrial or residential buildings near their placement. They gave meaning to their existence and allowed their exploitation. The variation in the sea level has also caused degradation or, at least, has threatened the survival of a large part of the archaeological sites where they were found.

Traditionally these constructions had been linked to both salting factories and production of garum, even though recent studies indicate that a large part of these facilities would be focused on a fish storage function for selective breeding and direct consumption (Olcina, 2015). They had also the aquarium aesthetic function to show the owner's social status.

The sites that were analyzed for this work about the Spanish coast are: Cape Trafalgar fish tank, La Albufereta of Alicante, Illeta dels Banyets in El Campello, Baños de la Reina in Calp, and Baños de la Reina in Xàbia. Those analyzed in the Italian Tyrrhenian Sea are: Santa Liberata, Pian di Spille, Torre
Valdaliga, La Mattonara, Punta dellaVipera, Torre Flavia, La Saracca, La Banca, Torre Astura, Sperlonga (Villa di Tiberio) and the fish tank of Ventotene island.

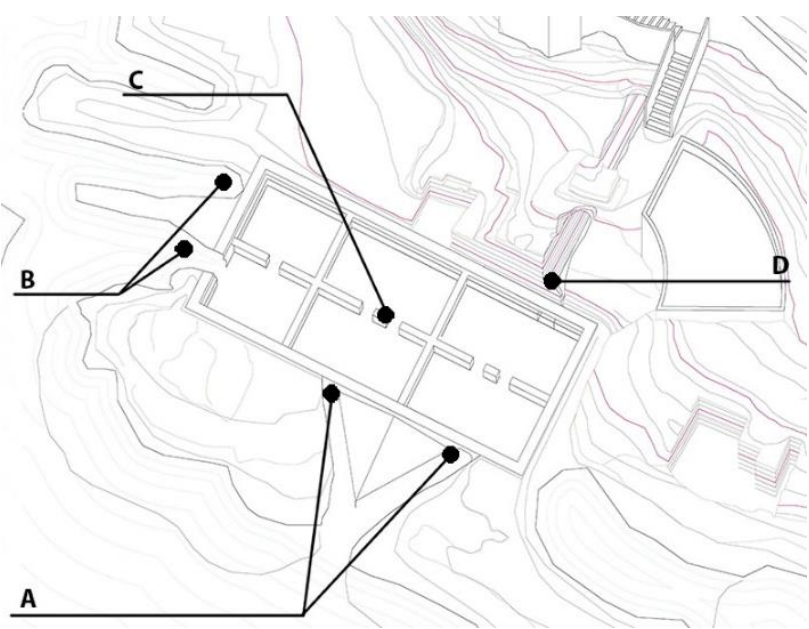

Figure 2. Fish farm type model, using the example of Baños de la Reina in Calp (Alicante): (A) Water supply channels, in the direction of the sea waves; (B) Water outlet channels; (C) Fish tank with internal subdivision; (D) Possible sweet water supply channel.

The following information is a description about the most significant and analyzed fish tanks of the Spanish and Italian coastlines. Name, location and characteristics are provided. There is also a small description of the current state of conservation and its situation regarding the sea level.

The fish tank of Cape Trafalgar (Cádiz, Spain) is a large rockcarved enclosure $(25 \times 8.5 \mathrm{~m})$, in the eastern part of the natural barrier where the lighthouse of Cape Trafalgar stands. It is not accurately known if it was an installation of this type or it had a different use. Nevertheless, it seems that a fish tank is the use that best fits due to its characteristics and position. It is a rectangular pool with carved edges and it is partially buried with beach sands (Figure 3). At high tide hours, it is completely submerged.

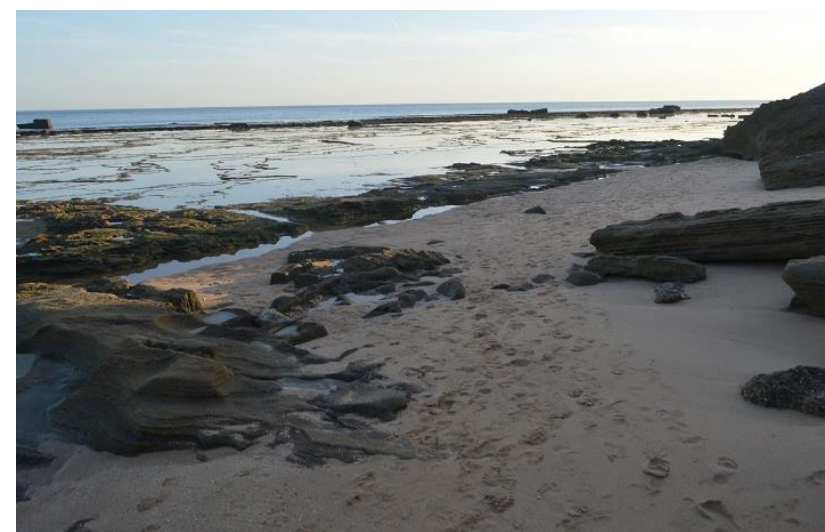

Figure 3. Tank of Cape Trafalgar, almost entirely buried, at a low tide. Author: F.J. Caballero (October 2018)

The Albufereta fish tank of Alicante is located in the north of the downtown. A small carved tank $(9 \times 5 \mathrm{~m})$ is identified in the coastal rock. The morphology of the installation can be clearly observed since it is above sea level, although it shows clear signs of erosion. Some loss of material is also observed in the water supply channels (Figure 4). 


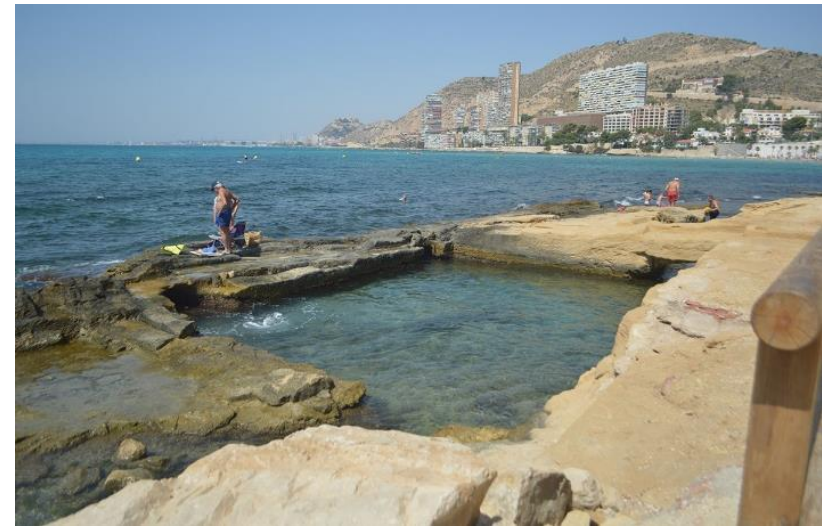

Figure 4. La Albufereta fish tank.

Author: F.J. Caballero (July 2018).

The Illeta dels Banyets fish tank in El Campello is composed of two differentiated enclosures; one is located in the south-west and the other in the east. The first one has two quadrangular basins, which suffered the most powerful erosion in recent years. Nowadays they are submerged most of the time. On the eastern tip of the site, three parallel quadrangular enclosures accompanied by another longitudinal cross-sectional one. Somehow, it supports erosion better as they have a greater volume of stone to protect it against the waves. However, erosion causes the emptying of the intermediate layer. This fact made already disappear the side of one of these basins. It mainly affects the sandstone layer in which the villae was developed. Although this archaeological site is partially musealised, erosion causes landslides endangering the stability of the whole.

The fish tank of Baños de la Reina in Calp has dimensions of $19.75 \times 8.50 \mathrm{~m}$. Its main side faces the south with two Y-shaped water access channels; on its west side it has two exits which facilitate the water renewal in the tanks. Its most exposed side to the waves (Figure 5) has a very low level, which is often covered by the sea. Meanwhile, in the back area towards the north, the rocky strata on which it was carved reaches several meters high.

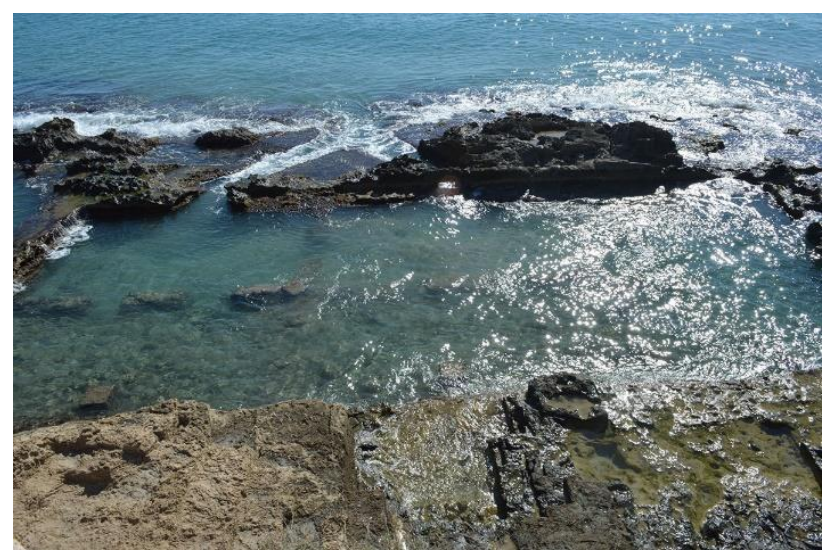

Figure 5. Fish tank of Baños de la Reina in Calp. Author: F.J. Caballero (February 2016)

The fish tank of Baños de la Reina or Punta de l'Arenal in Xàbia is located in the Muntanyar area, next to the National Tourism Parador. It is a rectangular enclosure $(27.30 \times 6.85 \mathrm{~m})$ excavated in the calcarenite of the fossil beach-rock. It is connected to the sea by two ditches of about $20 \mathrm{~m}$ in two different directions which are used to renew the water in the pools where the fish are. The volume of rock extracted from the large stone stratum and its low exposure to sea waves due to its more interior position, makes it the site of this type with less erosion. It is also the best preserved than those known in Spain. However, rising sea levels are submerging the internal elements of this installation.

Piscinae of Santa Liberata is located in the foothills of Monte Argentario, in the municipality of Porto Santo Stefano. This fish tank has a rectangular enclosure and was built with opus caementicium, roman concrete. Its interior dimensions about 25 $\mathrm{m} \times 50 \mathrm{~m}$ are divided into three parts; the first one is a square that occupies half of the pool. It is also the farthest from the shore. The other half was divided into two rectangular basins, one of them subdivided by diamond-shaped walls. The thickness of the perimeter walls is remarkable. It is practically submerged underwater and the highest area of the site was eroded by the sea, suffering its subsequent collapse.

Peschiera of Pian di Spille (Tarquinia) is located in a beach area that was divided by a promontory. It was formed by the remains of an ancient Roman villae in which the fish farm was associated. At the present, this promontory has been degraded so much due to the incidence of the sea. For this reason it is impossible to walk past the remains. The fish tank is inside the sea and it is located several meters away from the shore. Only the highest parts of the perimeter structure of the pool stand out above sea level.

Peschiera di Torre Valdaliga is located in the north of Civitavecchia. It is a fish tank completely excavated in the rock. It has a rectangular pool of $39 \times 19$ m with walls lined with opus reticulatum. It was connected to the sea through three channels oriented at different angles and with a small pool that was protected from waves by a stonewall. Part of the rocky platform where the tank is located, is currently submerged. In recent decades, the existence of the Torre Valdaliga Thermoelectric Plant has constrained the archaeological site, hiding access and obstructing its field of vision. At present, the experience of being in the place is not pleasant.

Peschiera di La Mattonara is located in the northern part of Civitavecchia town. It is completely excavated in the coastal sandstone rock, with no evidence of other constructions in the immediate environment. We talk about a rectangular pool of $16.50 \times 25.50 \mathrm{~m}$ approximately. It is surrounded by a ring perimeter which is divided into multiple smaller tanks. It forms a main set of $25 \times 35 \mathrm{~m}$. The water supply was produced through two radial arranged channels. In a stone barrier connected to this pool, there is another circular one known as 'Buca di Nerone'. It had the same fish tank function. Nowadays, the expansion of Civitavecchia port has created an artificial barrier of dikes in front of this heritage asset, which protects it from the waves, although it altered the visual field and took it away from its context.

Peschiera di Punta della Vipera is located in the south of Civitavecchia (northern area of Santa Marinella). It is a large fish tank (pool of $48 \times 30 \mathrm{~m}$ approximately), protected from waves by three large walls built with opus caementicium . It has a thickness of 2 and $3 \mathrm{~m}$. It is subdivided in three basins; the centre has a large circular pool (more than $20 \mathrm{~m}$ in diameter) and two more rectangular $4 \times 20.20 \mathrm{~m}$. Both of sides are subdivided into five other rectangular enclosures. They communicate each other through arches made of brick with a light of $2.20 \mathrm{~m}$. The whole seawater supply is stored through three vaulted galleries of about $20 \mathrm{~m}$ in length arranged almost perpendicular to the sea. There is a progressive submergence of this fish tank. 
Peschiera di Torre Flavia is located in the municipality of Campo di Mare (Marina di Cerveteri). It is a large circular pool with 47 $\mathrm{m}$ of diameter approximately. Nowadays it is almost submerged and there is no evidence to be observed from outside. It can only be identified by entering the sea on calm days.

Peschiera La Saracca is located in the south of Nettuno town, within the military area of Torre Astura. The access to this site is only allowed during the months of July and August. This is perhaps one of the most unique and best preserved site in the entire Mediterranean. It is a large fish tank built in opus caementicium. Its architectural plant is semicircular, reaching almost $90 \mathrm{~m}$ in diameter. It is externally protected by a wall of $3.50 \mathrm{~m}$ of thickness. It can be observed up to three concentric figures of tanks. However, the centre is covered by the beach sand and that is why it is difficult to perceive (Figure 6). It also has a spearhead in the most exposed part of the semicircle. It would serve to break the impact of the waves and direct the waters into the installation.

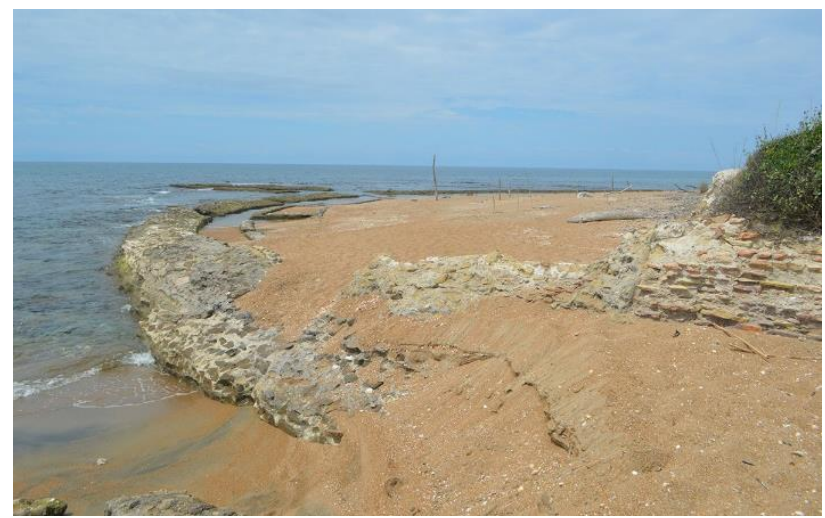

Figure 6. Peschiera La Saracca, partially buried by the sand of the beach. Author: F.J. Caballero (July 2019).

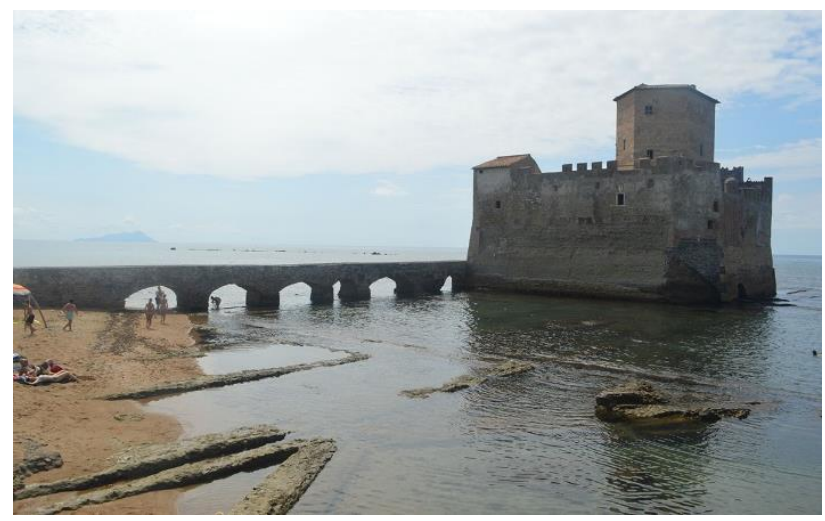

Figure 7. Peschiera di Torre Astura, partially covered by the defensive tower. Author: F.J. Caballero (July 2019).

Peschiera La Banca is close to the previously mentioned place. It is also located in the military area of Torre Astura. Due to this fact, its access is only allowed during the same period of time. There is a minimum attendance to the beach, because of the considerable distance that this heritage element has from the access point to the area. It is a well-preserved fish tank because a large part of its elements are in good and recognizable conditions. Its dimensions are $33.2 \times 20.3 \mathrm{~m}$. and $\mathrm{t}$ is subdivided in two tanks (Higginbotham, 1997). The main degradation of its elements is produced by the erosive effect of sea waves: it has already caused the partial destruction of the most exposed wall. It slightly stands out from the current sea level.
Peschiera di Torre Astura is also located in the south of Nettuno town, in the military area of Torre Astura. For this reason, it is subject to the same conditions than the previous ones. It is a large fish tank which forms a rectangle of $172 \times 125 \mathrm{~m}$. It is delimited by a wall of $2.5 \mathrm{~m}$ wide approximately, that retains a good part of its elements in recognizable conditions. The erosive effect of sea waves has caused the partial destruction of the most exposed wall. In addition, the construction of a defensive tower over a part of the installation produced the partial loss of elements of the farm (Figure 7).

Peschiera di Sperlonga (Villa di Tiberio) is located in the south of the municipality of Sperlonga, next to the foothills of a mountain that reaches the sea. The fish tank takes advantage of the existence of a natural cave to get in partially on it. Large statues were placed for the enjoyment of Emperor Tiberius in the inner cavern. This is the only Italian fish tank enhanced for tourism purposes. It is protected by an artificial sea breakwater and a thick concrete wall around the pool which acts as a barrier between the indoor museum and the outdoor space.

Peschiera from Ventotene Island (Figure 8) is one of the fish tanks excavated in a gallery form. These are two parallel domed enclosures, sculpted in the rock of a cliff coastal. It contains two basins to store the fish. The erosion, caused by sea waves and winds, detached the rock that functioned as a vault. At the present moment, the access is prohibited thanks to a fence that prevents any person who approaches by land. This is one of the few Italian fish tanks in the Tyrrhenian Sea that are exposed to the east winds and storms, besides to those located on Ponza island and the Tuscan archipelago.

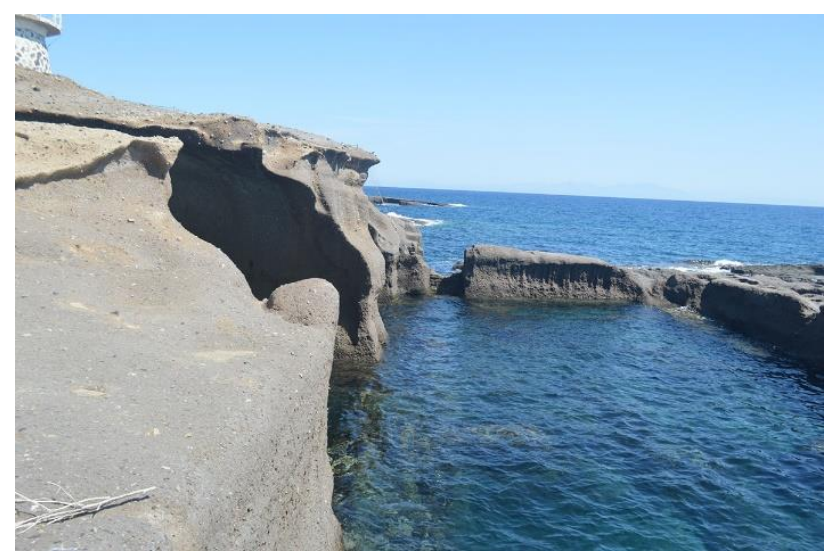

Figure 8. Peschiera di Ventotene, with two galleries excavated in the left part of the image. Author: F.J. Caballero (July 2019).

\section{CLIMATE CHANGE AND ROMAN COASTAL FISH TANKS}

The piscinae are heritage elements that are located at the edge of the sea as already mentioned. This entails consequences related to climate change. On the one hand, they become excellent indicators of the sea level position in Roman times. On the other hand, this fact places them in an extremely exposed and vulnerable position against marine erosive phenomena.

Regarding its value as an indicator of the marine level of 2000 years ago, it must be said that contributions from Schmiedt's pioneering work (1972), from others made about some of the tanks of the Tyrrhenian Sea (Lambeck, and Chappell, 2001; Lambeck et al., 2004), from sites treated in this work, and those carried out on the French Mediterranean coast (Morhange et al., 2013) it is proved the efficiency of this palaeoclimatic method to analyse sea level changes in the late Holocene period. 
It is estimated that these fish tanks were built around the 1st century B.C. and the 1st century A.D. (Olcina, 2015), bearing directly on the sea level at the time of construction. These well-preserved remains provide us information about the sea-level changes along with other biological methods, such as the well-preserved biological remains on the fish tank walls (Evelpidou et al., 2012).

The sea-level change is a measure of the relative vertical movement between land and sea surfaces. Any observed change reflects both land movement and change in ocean volume. Geological studies in the areas where the analysed piscinae are found, report that these areas were tectonically stable during the Late Quaternary. The observed changes could be basically attributed to changes in sea level. Guidoboni (1994) proved that the central Tyrrehenian coast was a stable tectonic area and devoid of major seismic activity for the past 2000 years. On the other hand, the continental edge of the Alicante coast has also remained quite stable during the Holocene, according to their geomorphological features and the occurrence of the Pleistocene palaeodeposits evidences (fossil marine terrasses, etc.). In fact, the city of Alicante was chosen as the benchmark for all Spain's measurements of altitude above the sea level. Thus, it can be said that tectonic factors were negligible on the studied settlements.

The previous mentioned scientific works conclude that the sea level was slightly lower at the present than during the Roman times, ranging from $-1.35 \pm 0,07 \mathrm{~m}$ for Lambeck et al. (2004), to $-40 \pm 10$ $\mathrm{cm}$ for Morhange et al. (2013) or Evelpidou et al. (2012) who proposed that the Roman sea level was ranging -32 to $-58 \pm 5 \mathrm{~cm}$. These detected discrepancies can be attributed to a different interpretation of the hydraulic position of fish tank structures relative to former sea level or also to different tectonic behaviour in each region, among others.

It is also necessary to mention the few Spanish Roman fish tank studies, referring to the study of marine levels. Rosselló (1999) was the only one analysing the surroundings of the Illeta dels Banyets in El Campello. He proposed that the sea, at this place, has risen and fallen, at least once, with a range of 0.5 to $0.8 \mathrm{~m}$ since its construction.

Since the fish thanks were built, the rise in the sea level, caused that many of these structures were partially submerged several centimetres below the current level of the sea. This is the case of the Torre Flavia, a circular pool whose remains are about $30 \mathrm{~cm}$ submerged in front of the beaches of the Marina di Cerveteri. In the decade of the ' $60 \mathrm{~s}$ of the 20th century, this site was still partially visible on the coast (Figure 9). In this place, the transgression of the coastline is clearly identified.

According to the studies of the Intergovernmental Panel on Climate Change (IPCC, 2013), the forecast is that, throughout the $21 \mathrm{st}$ century, the level of the sea will be $40-60 \mathrm{~cm}$ above the current one. This means that before the year 2100 all these examples of antiquity fish farming will be completely submerged.

A verifiable example of the effects that sea level rise is having, can be seen in the Peschiera di Pian di Spille (Figure 10), where the shoreline movements towards a higher ground of the coastline in few years, caused that the fish tank is now several meters inside the sea. Erosion also caused the lost of part of the site to which it was associated. This circumstance can be easily verified at the site or by observing historical aerial photos.

The phenomenon is repeated in the rest of fish tanks; thus, in the Peschiera di Santa Liberata, or in Punta della Vipera (Figure 11), the submergence of the vestiges of these fish tanks is also very remarkable. The comparison of images taken a few years ago with the current ones shows the differences in height.

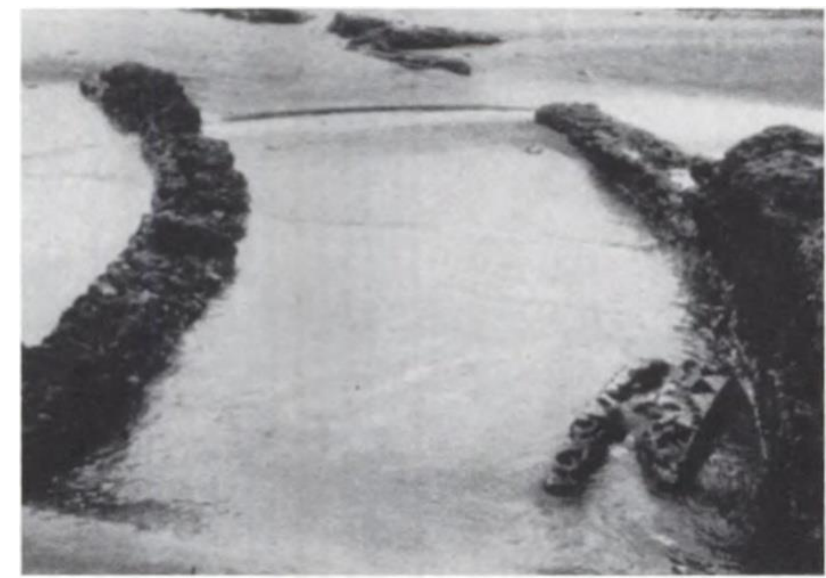

Figure 9. Remains still visible of the Peschiera di Torre Flavia in the 60s of the 20th century (From De Rossi et al., 1968).

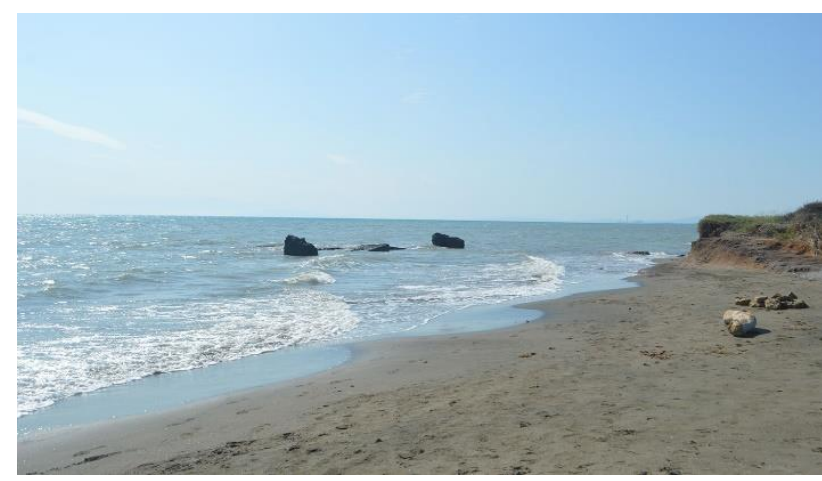

Figure 10. Peschiera di Pian di Spille nowadays. Author: F.J. Caballero (July 2019).
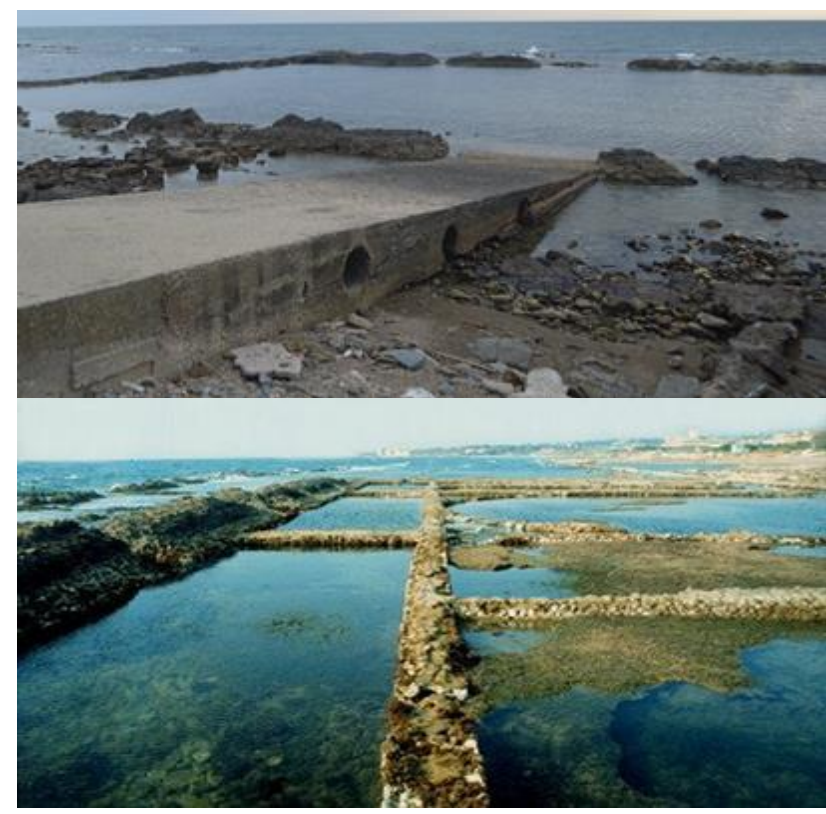

Figure 11. Peschiera di Punta della Vipera currently, Author:

F.J. Caballero (July 2019), compared with another image of the same place in undetermined previous date $(\mathrm{F}$ : http://portofrome.it)

In addition to the effects produced by the rise in the sea level, we must consider others also linked to climate change. Those are related to the frequency and intensity of current storms and 
marine phenomena that harms the conservation of these heritage elements. These phenomena, apart from affecting the fish tanks themselves, which are very exposed to the sea, impact on weaker areas behind them, at higher places. These latter areas are more susceptible to erosion and usually house areas with greater archaeological value. This is the case of all the existing archaeological Spanish sites of this type and many of those located on the Italian coast, such as the case of the Peschiera di Santa Liberata that is in full erosion process (Figure 12).

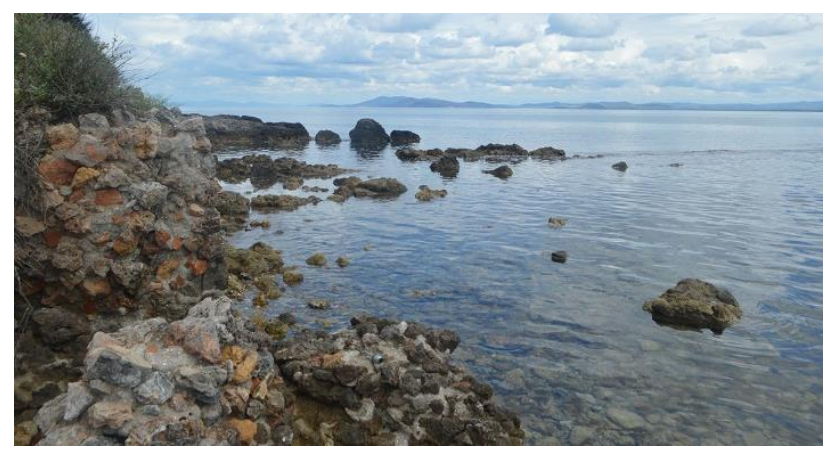

Figure 12. Fish tank of Santa Liberata with the submerged pool and the land area in the process of heavy erosion. Author: F.J. Caballero (May 2019).

The marine storms in the Mediterranean area, along with strong swells, as mentioned before, are often accompanied by torrential rains. They increase the erosive effect on the heritage sites, causing heavy runoffs and the loss of archaeological material from the land towards the sea. They also generate a temporary increase in the sea level in the whole area.

Thus, in the case of Spanish fish tanks, the temporary storm, increasingly frequent and more intense, affect, to a greater extent, the fish tank of Baños de la Reina de Xàbia, and the Illeta dels Banyets de El Campello (Figure 13), as in the existing tank at Cape Trafalgar. In the basins located in the west of El Campello site, there has been a rapid degradation of the heritage elements in the recent years; in a couple of years it went from an apparent robustness of the structure to a strong destruction of the element and the degradation of the whole (Pérez, 2015). Over the years, it has been observed a reduction of the isthmus surface on which the archaeological site is located, due to the incomplete wall structures on the margins of the platform.

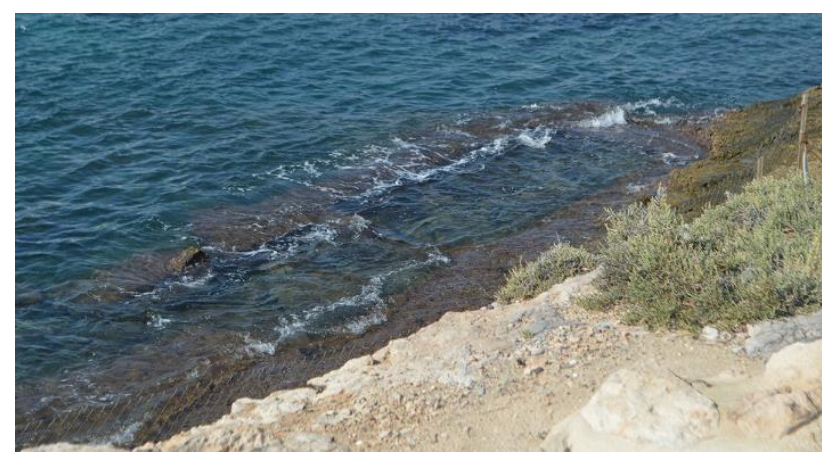

Figure 13. Western tanks of the Illeta dels Banyets currently. Author: F.J. Caballero (October 2018).

Meanwhile, the fish tank of Baños de la Reina de Calp (Figure 13) and the western tanks of the Illeta dels Banyets are more protected against these storms and east winds. However they are exposed to storms with south and west winds. Even so, these last two installations are somewhat protected by nearby artificial breakwaters. Anyway, comparing images with a few years of difference, it can be seen that the fish storage pool located in Calp, increased it submergence.

At this archaeological site, marine erosion over the continental zone has been slowed down by the construction of the seaside promenade, which acts as a containment element. However, the nature of the land, with a higher layer of calcareous sandstone (locally called 'piedra tosca'), better supports the impact of the waves than in the case of El Campello where the layer of this material is lower dimensioned.

In Italy, most of this kind of sites are exposed to storms with winds from west. The exception is the case of the islands, in which fish tanks are more exposed to winds from the east and many of them dug in gallery. This kind of island pools may be associated with commercial and communication relations with the continental zone.

\section{OTHER CONDITIONS}

In addition to the effects caused by climate change on these archaeological sites, it should be mentioned that they may be subject to other type of natural hazards such as volcanic eruptions and earthquakes. These phenomena can also cause variations in the sea level, as is the case of Baia, in the immediate vicinity of Naples, where there is evidence of the existence of a couple of fish tanks that have suffered the effect of bradisism. This is a phenomenon consisting in the rapid descent or elevation of the terrain (approximately $1 \mathrm{~cm}$ per year) due to variations produced in the magma chamber existing in the subsoil (Del Gaudio, et al., 2014). Thus, at the present, these sites are submerged several meters below the level of the sea and it is only possible to observe them from underwater dives.

Moreover, there is another impact that coastal infrastructures such as certain industries or ports have. This is the case of the Peschiera di Torre Valdaliga (Figure14) or that of the Peschiera della Mattonara where there have been great changes in the environment of these fish farms.

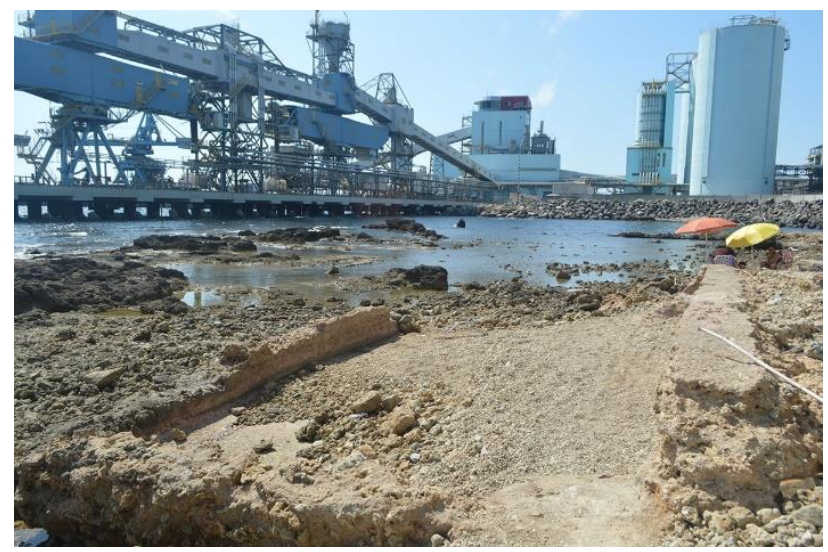

Figure 14. Peschiera di Torre Valdaliga. Author: F.J. Caballero (October 2018).

The construction of breakwaters, groins and other elements that are located in the sea for the defence of beaches or port structures can also cause alterations of marine dynamics along the coastline (drift currents, etc.), increasing the deposit of materials to upwind, while downwind there is a great erosion of the coast (Ibarra, et al., 2017). This circumstance can influence the stability of the coastal archaeological sites that are located near these structures, especially those downwind from them. 
Below is a summary table with the previously analyzed agents of degradation and the generated causes (Figure 15):

\begin{tabular}{|l|l|}
\hline \multicolumn{1}{|c|}{ Agents of degradation } & \multicolumn{1}{c|}{ Causes } \\
\hline Sea level change & $\begin{array}{l}\text { Submergence } \\
\text {-Hidden items }\end{array}$ \\
\cline { 2 - 2 } & $\begin{array}{l}\text { Direct erosion } \\
\text {-Damage to the element itself } \\
\text {-Wall concavities }\end{array}$ \\
\cline { 2 - 2 } & $\begin{array}{l}\text { Indirect erosion } \\
\text {-Detachment of adjacent } \\
\text { areas on the elements }\end{array}$ \\
\hline Coastline disturbances & Alteration of the visual field \\
\hline Edification on the elements & Damage or loss of items \\
\hline Construction of breakwaters & $\begin{array}{l}\text { Alteration of sea currents } \\
\text {-Increased accumulation of } \\
\text { sediment } \\
\text {-Increased effect of waves in } \\
\text { certain areas }\end{array}$ \\
\hline
\end{tabular}

Figure 15. Summary table with the agents of degradation and generated causes.

\section{CORRECTIVE AND PREVENTIVE MEASURES}

To counteract the effects of the sea level rise and the others described before, some measures can be taken, by seeking that heritage elements suffer as little as possible their consequences. Thus, the establishment of physical protection barriers is a common measure that is been used for heritage conservation.

In the case of Peschiera della Mattonara (Figure 16), it is observed that the creation of physical barriers, as a consequence of the port area expansion is a radical but effective solution for the conservation and protection of the heritage element, since it is protected from the waves.

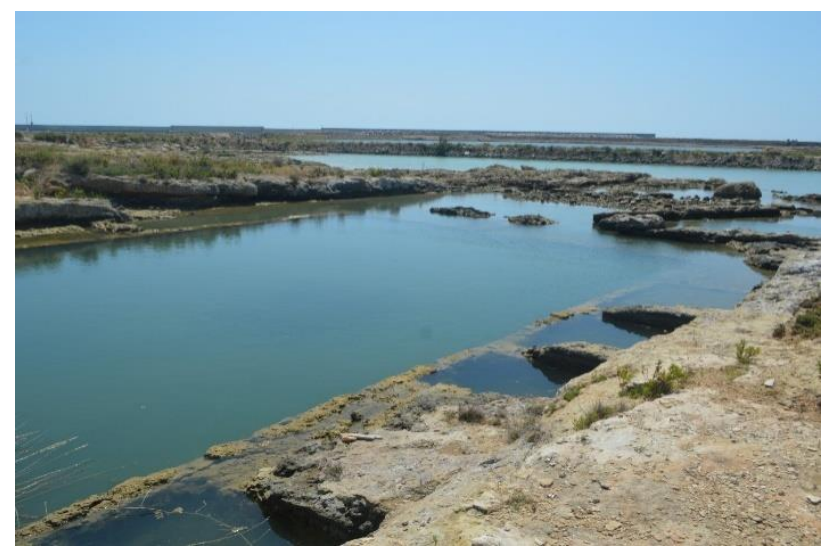

Figure 16. Peschiera della Mattonara with artificial dykes that protect it involuntarily. Author: J. Caballero (July 2019).

Another example of the creation of physical protections for the preservation of Roman fish tanks is the case of Villa di Tiberio, in Sperlonga town: the only enhanced site for visits, as mentioned above. Thus, around what was the original Roman pool, which is built into a conditioned natural cavity, a powerful concrete wall was erected to protect it from the eventual pernicious effect produced by the sea. On the outside of this wall, an artificial dike exists to stop the impact of the beating of the waves (Figure 17).
For the fish basins located in the southwest of the Illeta dels Banyets (El Campello), a project was drafted in 2013 for the partial consolidation of the heritage element because it is in direct contact with the sea (Pérez, et al., 2013). This project has not yet been implemented due to the technical complexity and economic cost involved, for which there has been no budget item.

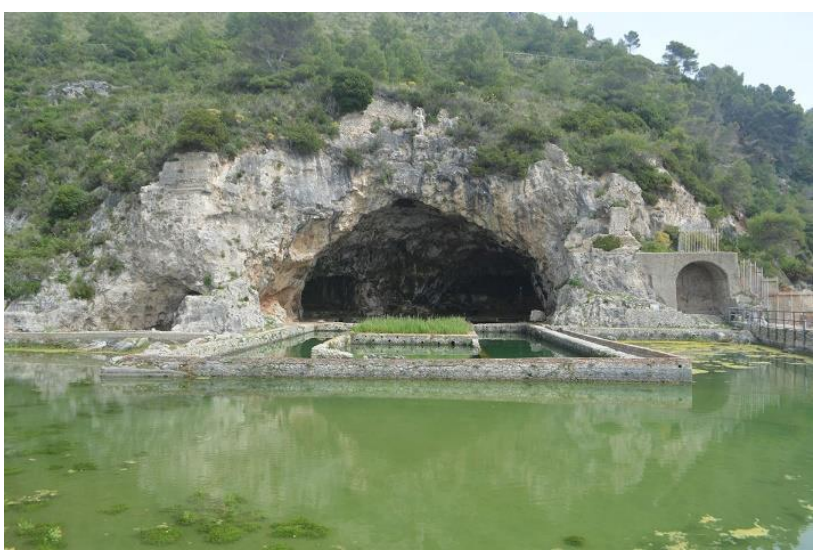

Figure 17. Peschiera di Villa di Tiberio in Sperlonga. Author: F.J. Caballero (April 2019).

\section{CONCLUSION}

It is difficult to avoid the damages of the Roman fish tanks in the Mediterranean due to the rise of the sea level. Thus, unless drastic preservation measures are taken, which allow to maintain, as far as possible, the current conditions in which the archaeological sites are, marine dynamics will exert a constant degradation on them that will cause irreparably losseson the heritage elements.

The rise in the sea level is a studied phenomenon whose prognosis points towards a rise in the coming years. This will cause that, towards the end of the century, all of these elements will practically be below the current sea level, being only visible the carved footprints in the natural rock that stand out in some of these places.

It is necessary to remember that, if it is decided to take protective measures or investing in research, projects will be made for the enhancement of this type of archaeological sites. For that reason, it is important to take into account the effects of the sea level rise. It is also required to avoid, as far as possible, the lost of any investment in a short period of time, due to the action of any of the elements mentioned in this article.

In addition, we must be aware that, probably in a few years, the only way to enjoy the remains of these places, which are a sign of the human desire to control maritime production and supply, it will be through underwater dives.

\section{REFERENCES}

Abascal, J.M., Cebrián, R., Ronda, A. Sala, F., 2007: Baños de la Reina de Calpe. Un vicus romano a los pies del Peñón de Ifach, Calpe. Ed.Council ofCalp.Calp, Alicante.

Bernal, D., 2011: Piscicultura y ostriculturaenBaetica. Nuevostiempos, nuevascostumbres. In D. Bernal (ed.): Pescar con Arte. Fenicios y romanosen el origen de los aparejosandaluces. Ed. University of Cádiz. Cádiz: 137-159. 
Bernal, D., 2015: Viveros y yacimientoshaliéuticos. Importancia y fragilidad del patrimoniopesquero-conserverohispanorromano. In M. Olcina, and R. Pérez (eds): La IlletadelsBanyets y los viverosromanos de la costa mediterráneaespañola. Cuestión de conservación. Ed. MARQ - Archaeological Museum of Alicante. Alicante: 16-41.

De Rossi, G.M, di Domenico P.G., and Quilici, L., 1968: La via Aurelia da Roma a Forum Aureli. In Quadernodell'Istituto di Topografia Antica dellaUniversità di Roma 4, Roma

Del Gaudio, C., Aquino, I., Di Vito, M.A., Ricco, C., 2014: Giuseppe Mercalli e lo studio del bradisismoflegreo. Miscellanea INGV. 24., Napoli: 71-77.

Evelpidou, N., Pirazzoli, P., Vassilopoulos, A., Spada, G., Ruggieri, G. and Tomasin, A., 2012: Late Holocene Sea Level reconstructions based on observations of Roman fish tanks, Tyrrhenian Coast of Italy.Geoarchaeology: An International Journal 27: 259-277.

Giacopini, L., Marchesini, B., Rustico, L., 1994: L'Itticolturanell'Antichità, Ed. IGER. Roma.

Guidoboni, E., 1994: Catalogue of Ancient Earthquakes in the Mediterranean Area Up to the 10th Century, Istituto Nazionale di Geofisica, Rome, 504 pp.

Higginbotham, J., 1997: Piscinae, Artificial Fishponds in Roman Italy. Ed. The University of North Carolina Press. Chapel Hill London.

Ibarra, D., Belmonte, F., 2017: Comprendiendo el litoral: dinámica y procesos. Ed. University of Murcia. Murcia.

IPCC, 2013: Climate Change 2013: The Physical Science Basis, Cambidge - New York.

Lambeck, K. and Chappell, J. 2001: Sea level change through the last glacial cycle. Science, 292: 679-686.

Lambeck, K., Anzidei, M., Antonioli, F., Benini, A., Esposito, A., 2004: Sea level in Roman time in the Central Mediterranean and implications for recent change. Earth and Planetary Science Letters, 224: 563-575.

Morhange, Ch., Marriner, N., Excoffon, P., Bonnet, S., Flaux, C., Zibrowius, H., Goiran, J.Ph., and El Amouri, M., 2013: Relative Sea-Level Changes During Roman Times in the Northwest Mediterranean: The 1st Century A.D. Fish Tank of Forum Julii, Frejus, France Geoarchaeology: An International Journal, 28: 363-372

Olcina, M., 2015: Los viverosromanos de la costa alicantina. In M. Olcina and R. Pérez (eds): La IlletadelsBanyets y los viverosromanos de la costa mediterráneaespañola. Cuestión de conservación. Ed. MARQ - Archaeological Museum of Alicante. Alicante: 42-63.

Pérez, R., 2015: La musealización y la conservación del yacimiento de la IlletadelsBanyets. In M. Olcina and R. Pérez (eds): La IlletadelsBanyets y los viverosromanos de la costa mediterráneaespañola. Cuestión de conservación. Ed. MARQ Archaeological Museum of Alicante. Alicante: 98-111.
Pérez, R., Olcina, M. and Alonso, J., 2013: Proyecto de ejecución para la consolidación y estabilización de los viverosromanos del yacimientoarqueológico de la IlletadelsBanyets.Technical Report, Council of El Campello, Alicante.

Rosselló, V., 1999: La IlletadelsBanyets del Campello: nivellsmarinsiarqueologia al migjornvalencià. In:Geoarqueologia I Quaternarilitoral. Memorial M.P. Fumanal. Ed. Universitat de València.Valencia: 229-243.

Schmiedt, G., 1972: Il livello antico del mar Tirreno. Testimonianzedeirestiarcheologici, Ed. Olschki. Firenze. 